\title{
Phosphorus utilization by corn as affected by green manure, nitrogen and phosphorus fertilizers
}

\author{
Edson Cabral da Silva(1), Takashi Muraoka(1), Vinícius Ide Franzini(2), Felipe Carlos Alvarez Villanueva(1), \\ Salatiér Buzetti( ${ }^{(3)}$ and Dolorice Moreti( ${ }^{(4)}$
}

\begin{abstract}
(1)Universidade de São Paulo, Centro de Energia Nuclear na Agricultura, Caixa Postal 96, CEP 13416-000 Piracicaba, SP, Brazil. E-mail: ecsilva@cena.usp.br, muraoka@cena.usp.br, falvarez@cena.usp.br (2)Embrapa Amazônia Oriental, Caixa Postal 48, CEP 66095-100 Belém, PA, Brazil. E-mail: vinicius.franzini@embrapa.br ${ }^{(3)}$ Universidade Estadual Paulista, Faculdade de Engenharia de Ilha Solteira, Caixa Postal 31, CEP 15385-000 Ilha Solteira, SP, Brazil. E-mail: sbuzetti@agr.feis.unesp.br (4)Empresa Matogrossense de Pesquisa, Assistência e Extensão Rural, Caixa Postal 225, CEP 78068-690 Cuiabá, MT, Brazil. E-mail: dmoreti@gmail.com
\end{abstract}

\begin{abstract}
The objective of this work was to evaluate the utilization by corn plants of P from triple superphosphate fertilizer labeled with ${ }^{32} \mathrm{P}\left({ }^{32} \mathrm{P}-\mathrm{TSP}\right)$, and of $\mathrm{P}$ from soil as affected by $\mathrm{N}$ rates and by the green manures (GM) sunn hemp (Crotalaria juncea) and millet (Pennisetum glaucum). The experiment was carried out using pots filled with $5 \mathrm{~kg}$ Oxisol (Rhodic Hapludox). A completely randomized design was used, in a $4 \times 4 \times 2$ factorial arrangement, with four replicates. The treatments were: four P rates as TSP $(0,0.175,0.350$, and $0.700 \mathrm{~g} \mathrm{P}$ per pot); four $\mathrm{N}$ rates as urea $(0,0.75,1.50$, and $2.25 \mathrm{~g} \mathrm{~N}$ per pot); and sunn hemp or millet as green manure. The additions of $\mathrm{N}$ and $\mathrm{P}$ by the GM were taken into account. After grain physiologic maturation, corn dry matter, $\mathrm{P}$ contents, accumulated $\mathrm{P}$, and $\mathrm{P}$ recovery in the different treatments were measured. ${ }^{32} \mathrm{P}-\mathrm{TSP}$ recovery by corn increased with $\mathrm{N}$ increasing rates, and decreased with increasing rates of ${ }^{32} \mathrm{P}-\mathrm{TSP}$. The mineral fertilizer provides most of the accumulated $\mathrm{P}$ by corn plants. The recovery of ${ }^{32} \mathrm{P}$-TSP by corn was $13.12 \%$ in average. The green manure species influence the assimilation of ${ }^{32} \mathrm{P}-\mathrm{TSP}$ by the plants.
\end{abstract}

Index terms: Zea mays, cover crop, isotopic dilution, Oxisol, radioisotope, urea.

\section{Aproveitamento do fósforo pelo milho influenciado por adubação verde, nitrogenada e fosfatada}

Resumo - O objetivo deste trabalho foi avaliar a utilização, pela planta de milho, do P proveniente de superfosfato triplo marcado com ${ }^{32} \mathrm{P}$ ( $\left.{ }^{32} \mathrm{P}-\mathrm{SFT}\right)$, e do $\mathrm{P}$ proveniente do solo influenciado por doses de $\mathrm{N}$ e pelos adubos verdes (AV) crotalária (Crotalaria juncea) e milheto (Pennisetum glaucum). O experimento foi realizado em vasos com $5 \mathrm{~kg}$ de Latossolo Vermelho distroférrico. Utilizou-se o delineamento inteiramente casualizado, em arranjo fatorial $4 \times 4 \times 2$, com quatro repetições. Os tratamentos foram: quatro doses de P, na forma de SFT $(0,0,175,0,350$ e $0,700 \mathrm{~g}$ de $\mathrm{P}$ por vaso); quatro doses de $\mathrm{N}$, na forma de ureia $(0,0,75,1,50$ e $2,25 \mathrm{~g}$ de $\mathrm{N}$ por vaso); e crotalária ou milheto, como adubo verde. Foram levadas em consideração as adições de $\mathrm{P}$ e $\mathrm{N}$ pelos AV. Após a maturação fisiológica dos grãos, foram avaliados: a produção de matéria seca de milho, o teor de $\mathrm{P}$, o $\mathrm{P}$ acumulado e o aproveitamento de $\mathrm{P}$ nos diferentes tratamentos. $\mathrm{O}$ aproveitamento do ${ }^{32} \mathrm{P}$-SFT pelo milho aumentou com o incremento da dose de $\mathrm{N}$ e diminuiu com o aumento da dose de ${ }^{32} \mathrm{P}-\mathrm{SFT}$. O fertilizante mineral fornece a maior parte do $\mathrm{P}$ acumulado nas plantas de milho. O aproveitamento do ${ }^{32} \mathrm{P}-\mathrm{SFT}$ pelo milho foi de 13,12\%, em média. A espécie de adubo verde influencia a assimilação de ${ }^{32} \mathrm{P}-\mathrm{SFT}$ pelas plantas.

Termos para indexação: Zea mays, plantas de cobertura, diluição isotópica, Latossolo, radioisótopo, ureia.

\section{Introduction}

Phosphorus deficiency is a major constraint to crop production in most tropical and subtropical acid soils, and $\mathrm{P}$ fertilizers are required to sustain optimum crop yields (Pypers et al., 2005; Nachimuthu et al., 2009). In Brazil, low soil $\mathrm{pH}$, combined with incorrect management of $\mathrm{N}$ and $\mathrm{P}$ fertilizations, is the main responsible for low corn yields. In addition to that, soil acidity results in high $\mathrm{P}$ fixation (Novais et al., 2007).
The strong interaction of $\mathrm{P}$ with soil colloids, which results in widespread lack of $\mathrm{P}$ in Brazilian soils and decreases the response to fertilization, mainly in the Oxisols (Novais et al., 2007). In addition to that, low $\mathrm{N}$-nitrate absorption can further reduce corn yields compared to the ones expected only from $\mathrm{P}$ availability (Lee et al., 1992). Marschner (2011) and Schlegel et al. (1996) mention that the positive influence of $\mathrm{N}$ on $\mathrm{P}$ uptake by corn is high, mainly due to a greater root 
system development and growth, which can mitigate the low P diffusive flow in the soil (Marschner, 2011). Also, $\mathrm{N}$ can increase the mineralization of organic $\mathrm{P}$ by soil microorganisms (Novais et al., 2007).

Chemical fertilizers are the major sources of $\mathrm{P}$ in both developed and developing countries, since the organic P sources, such as crop residues, generally have low $\mathrm{P}$ contents, which would demand massive amounts to provide adequate $P$ rates, usually rendering their application economically unfeasible (Chien et al., 2011).

Green manure (GM) is essential in highly weathered soils such as Oxisols, in which cation exchange capacity are highly dependent on soil organic matter (Spera et al., 2006). In these conditions, liming and fertilization are usually not enough to reach economic crop yields (Spera et al., 2006; Carvalho et al., 2011). The importance of GM has increased recently, because it is an important strategy to maintain or to improve soil fertility for sustainable crop production (Fageria, 2007).

Phosphorus availability in tropical acid soils is enhanced by the combined use of fertilizers and GM, due to the dissolution of sparingly soluble P sources and reduced $\mathrm{P}$ retention (Haynes \& Mokolobate, 2001; Bah et al., 2006). Thus, one possible, effective $\mathrm{P}$ fertilization strategy is to incorporate green manures into soil - mainly $\mathrm{P}$ accumulating crops - along with water soluble P fertilizers. This would supply readily available $\mathrm{P}$ to the crops in the early growth phase (Grant et al., 2001), and the P from organic residues could become available further on (Ryan et al., 2007).

Studies using the ${ }^{32} \mathrm{P}$ tracer methodology on the $\mathrm{P}$ dynamics in the soil-plant system, mainly evaluating the efficiency of soluble phosphate fertilizers, have shown that the crops rarely utilize more than $10 \%$ of the applied amount (Franzini et al., 2009).

The objective of this work was to evaluate the utilization by corn plants of phosphorus from triple superphosphate fertilizer labeled with ${ }^{32} \mathrm{P}$, and of $\mathrm{P}$ from soil as affected by $\mathrm{N}$ rates and the green manures sunn hemp (Crotalaria juncea L.) and millet (Pennisetum glaucum L.).

\section{Materials and Methods}

The experiment was carried out in a greenhouse at the Centro de Energia Nuclear para Agricultura (Cena/USP), state of São Paulo, Brazil, at 22 $2^{\circ} 2^{\prime} 30^{\prime \prime S}$, $47^{\circ} 38^{\prime} 0^{\prime \prime} \mathrm{W}, 554 \mathrm{~m}$ altitude.
The study was done with clay texture soil $\left(440 \mathrm{~g} \mathrm{~kg}^{-1}\right.$ of clay), collected from the 0 to $0.20 \mathrm{~m}$ soil depth of a Rhodic Hapludox according to United States (2006), classified as the Brazilian soil Latossolo Vermelho distroférrico, loamy, Cerrado phase by Santos et al. (2006). The soil chemical properties (Raij et al., 2001) were: $\mathrm{pH}\left(\mathrm{CaCl}_{2}\right), 4.8$; total $\mathrm{N}, 1.0 \mathrm{~g} \mathrm{~kg}^{-1}$; OM, $12.7 \mathrm{~g} \mathrm{dm}^{-3}$; resin-extractable $\mathrm{P}, 11.7 \mathrm{mg} \mathrm{dm}^{-3}$; $\mathrm{S}, 7.5 \mathrm{mg} \mathrm{dm}{ }^{-3}$; soil $\mathrm{CEC}, 5.8 \mathrm{cmol}_{\mathrm{c}} \mathrm{dm}^{-3} ; \mathrm{K}$, $0.2 \mathrm{cmol}_{\mathrm{c}} \mathrm{dm}^{-3} ; \mathrm{Ca}, 2.0 \mathrm{cmol}_{\mathrm{c}} \mathrm{dm}^{-3}, \mathrm{Mg}, 1.0 \mathrm{cmol}_{\mathrm{c}} \mathrm{dm}^{-3}$; $\mathrm{H}+\mathrm{Al}, 2.6 \mathrm{cmol}_{\mathrm{c}} \mathrm{dm}^{-3}$; $\mathrm{SB}$ (sum of base), $3.2 \mathrm{cmol}_{\mathrm{c}} \mathrm{dm}^{-3}$; V\% (base saturation), $55.5 \%$.

Initially, plastic pots lined with polyethene bags, containing $5 \mathrm{~kg}$ soil, were used to produce the biomass of the green manures (GM). Twenty-five pots received 12 seeds each of sunn hemp ( $C$. juncea, cv. IAC KR1) or millet (P. glaucum, cv. ADR-500); five days after emergence (DAE), seedlings were thinned to six plants per pot. Plant shoots and roots were harvested at $70 \mathrm{DAE}$, rinsed with deionized water, oven-dried at $70^{\circ} \mathrm{C}$, weighed, and fragmented into pieces of approximately $2 \mathrm{~cm}$. A representative subsample of each GM was ground to $0.149 \mathrm{~mm}$ in a Wiley mill, for chemical analyses. After digestion with nitric-perchloric acid, the total $\mathrm{P}$ concentration was determined by the colorimetric method (Sarruge \& Haag, 1974) method. Total $\mathrm{N}$ was determined by the Kjeldahl method, after digestion with $\mathrm{H}_{2} \mathrm{SO}_{4}$ (Malavolta et al., 1997). Total C was analyzed by dry combustion at $1,400^{\circ} \mathrm{C}$ in an elemental analyzer Leco CN 2000 (Leco Corp., St. Joseph, MI, USA). Then, the $\mathrm{C} / \mathrm{N}$ and $\mathrm{C} / \mathrm{P}$ ratios were determined.

Shoot contents of C, N and P, in sunn hemp, were 430, 23.9 , and $3.4 \mathrm{~g} \mathrm{~kg}^{-1}$, respectively; in roots, they were $429,19.5$ and $1.8 \mathrm{~g} \mathrm{~kg}^{-1}$. In millet, the shoot contents of $\mathrm{C}, \mathrm{N}$, and $\mathrm{P}$ were $612,17.5$, and $3.2 \mathrm{~g} \mathrm{~kg}^{-1}$, respectively; in roots they were $392,11.9$, and $1.7 \mathrm{~g} \mathrm{~kg}^{-1}$.

In another 128 pots, corn plants were grown, by combining GM residues with or without rates of $\mathrm{N}$ and $\mathrm{P}$ fertilizers, with the main purpose of evaluating the effect on P uptake. The amount of GM dry matter mixed to the soil (shoot/root ratio of 4:1) was the one necessary to provide $1.0 \mathrm{~g} \mathrm{~N}$ per pot (52 g of sunn hemp and $78 \mathrm{~g}$ of millet). This amount, however, resulted in different additions of $\mathrm{P}-0.16 \mathrm{~g}$ per pot with sunn hemp, and $0.22 \mathrm{~g}$ per pot with millet - which is equivalent to 9.6 and $13.2 \mathrm{~kg} \mathrm{ha}^{-1} \mathrm{P}$, respectively. The soil was watered using deionized water $\left(0.6 \mu \mathrm{S} \mathrm{cm}^{-1}\right)$, 
and incubated for 10 days, before corn sowing, and soil-water content was kept at approximately $60 \%$ of the retention capacity.

A completely randomized design with 32 treatments was used, in a 4x4x2 factorial arrangement, with four replicates. The treatments were the combination of four $\mathrm{P}$ rates as ${ }^{32} \mathrm{P}-\mathrm{TSP}(0,0.175,0.350$ and $0.700 \mathrm{~g}$ $\mathrm{P}$ per pot, equivalent to $0,10.5,21$, and $42 \mathrm{~kg} \mathrm{ha}^{-1} \mathrm{P}$ ); four $\mathrm{N}$ rates as urea $(0,0.75,1.50$ and $2.25 \mathrm{~g} \mathrm{~N}$ per pot, equivalent to $0,45,90$, and $180 \mathrm{~kg} \mathrm{ha}^{-1} \mathrm{~N}$ ); and two $\mathrm{GM}$ - sunn hemp and millet. The rates of $\mathrm{N}$ and $\mathrm{P}$ were based in a corn stand of 60.000 plants ha ${ }^{-1}$.

Phosphorus rates as ${ }^{32} \mathrm{P}$-TSP, with specific activity of $80 \mathrm{kBq}^{32} \mathrm{P} \mathrm{mg}^{-1}$ of $\mathrm{P}$, were applied to soil in furrows, at an approximate $5 \mathrm{~cm}$ depth. Three corn seeds of a single hybrid (Pioneer 30F33) were sown in each pot, and thinned to one plant at $5 \mathrm{DAE}$. The $\mathrm{N}$ rates as urea were applied in two occasions: $0.375 \mathrm{~g} \mathrm{~N}$ per pot as basal fertilizer, and the remaining portion in topdressing, when plants showed four totally expanded leaves (line of sheet-hem union easily visible). In all treatments, $\mathrm{KCl}$ was applied at $150 \mathrm{mg} \mathrm{K}$ per pot.

Plant shoots were harvested at $120 \mathrm{DAE}$, after grain physiologic maturation, by cutting the plants at $1 \mathrm{~cm}$ above the soil surface. Shoots were oven-dried at $60^{\circ} \mathrm{C}$, weighed, and ground at $0.42 \mathrm{~mm}$ in a Wiley mill. Shoot samples of $0.5 \mathrm{~g}$ were digested with nitric-perchloric acid, and diluted to $50 \mathrm{~mL}$ with deionized water. An aliquot of $20 \mathrm{~mL}$ was used to measure the ${ }^{32} \mathrm{P}$ activity in a liquid scintillation counter by Cerenkov effect (L'Annunziata, 1987), and the total P concentration was determined by colorimetric method (Sarruge \& Haag, 1974). Total $\mathrm{N}$ was determined by Kjeldahl method, after digestion with $\mathrm{H}_{2} \mathrm{SO}_{4}$ (Malavolta et al., 1997).

Data from $\mathrm{P}$ content and ${ }^{32} \mathrm{P}$ activity were used to determine the specific activity and the proportion (\%Pdff) and amount (mg per pot), in plants, of $\mathrm{P}$ derived from ${ }^{32} \mathrm{P}$-TSP or from soil plus green manure (\%PdfS+GM), by calculations according to the isotopic dilution method (Vose, 1980; Hocking et al., 1997), using the following equations: $\% \mathrm{Pdff}=\mathrm{SA}_{\text {shoot }} / \mathrm{SA}_{\text {fertilizer }}$ x 100, and \%PdfS+GM $=100-\%$ Pdff; in which: $\mathrm{SA}_{\text {shoot }}$ is the specific activity of ${ }^{32} \mathrm{P}$ in plant shoot, according to the ratio between ${ }^{32} \mathrm{P}_{\text {shoot }}$ and ${ }^{31} \mathrm{P}_{\text {shoot }}\left[\mathrm{kBq}(\mathrm{mg} \mathrm{P})^{-1}\right]$; and $\mathrm{SA}_{\text {fertilizer }}$ is the specific activity of $\mathrm{P}$ derived from fertilizer, according to the ratio between ${ }^{32} \mathrm{P}_{\text {fertilizer }}$ and ${ }^{31} \mathrm{P}_{\text {fertilizer }}\left[\mathrm{kBq}(\mathrm{mg} \mathrm{P})^{-1}\right]$.
In corn shoot, the quantity of $\mathrm{P}$ derived from ${ }^{32} \mathrm{P}-\mathrm{TSP}$ (QPdff) and from soil plus green manure (QPdfS+GM) was calculated by the equations, $\mathrm{QPdff}=\% \mathrm{Pdff} \times \mathrm{QP}_{\text {shoot }} / 100$ and $\mathrm{QPdfS}+\mathrm{GM}=\% \mathrm{PdfS}$ + GM x $\mathrm{QP}_{\text {shoot }} / 100$, in which: $\mathrm{QP}_{\text {shoot }}$ is the amount of ${ }^{31} \mathrm{P}_{\text {shoot }}$ in shoot dry matter (mg). Phosphorus recovery from ${ }^{32} \mathrm{P}-\mathrm{TSP}$ fertilizer $(\% \mathrm{PRec})$ was calculated by the equation $\% \mathrm{PRec}=\left(\mathrm{QPdff} /{ }^{32} \mathrm{P}_{\text {applied }}\right) \times 100$, in which: ${ }^{32} \mathrm{P}_{\text {applied }}$ is the amount of $\mathrm{P}$ applied as ${ }^{32} \mathrm{P}$-TSP.

The obtained data were subjected to analysis of variance and, when significant effects were detected at $5 \%$ probability, the factors were adjusted to regression equations. Lineal and quadratic components were tested, and the model with larger significant degree was chosen. The statistical analyses were performed using SAS package (SAS Institute, 2001).

\section{Results and Discussion}

The $\mathrm{C} / \mathrm{N}$ ratio was similar in sunn hemp shoots and roots of ( $18 \pm 2$ vs. $21 \pm 2$, respectively), and was lower than that of millet ( $35 \pm 2$ and $33 \pm 1$, respectively). When $\mathrm{C} / \mathrm{N}$ ratio is less than 25 , organic matter mineralization and nutrient release are favored (Carvalho et al., 2008; Silva et al., 2008). However, this process is intrinsically related to soil texture and to climatic conditions, especially temperature and humidity (Lara Cabezas et al., 2004).

The C/P ratio for both sunn hemp and millet was higher in roots ( $238 \pm 5$ and $231 \pm 6$, respectively) than in shoots (126 \pm 7 and $191 \pm 8$, respectively). Due to the difficulties involved in quantifying belowground biomass, few studies attempted to distinguish aboveand belowground $\mathrm{N}$ or $\mathrm{P}$ inputs (Choi et al., 2008; Silva et al., 2008).

At harvest, regardless of the GM applied to the soil, shoot dry matter yield of corn plants increased in a quadratic form according to $\mathrm{P}$ rates (Figure $1 \mathrm{~A}$ ). The maximum productivity was reached with similar $\mathrm{P}$ rates for both GM: 0.51 and $0.50 \mathrm{~g} P$ per pot, respectively, for sunn hemp and millet. Due to the low values of available $\mathrm{P}$ in the soil, there was a high increase in the dry matter weight of corn plants after the addition of the first P rate, with lower increases in the subsequent rates. The quadratic increase in the dry matter yield in response to P rates is commonly observed (Chien et al., 1996; Franzini et al., 2009).

Regardless of $\mathrm{P}$ and $\mathrm{N}$ rates, the highest dry matter yield was observed for sunn hemp as GM 
(Figure $1 \mathrm{~A}$ ). At the highest $\mathrm{P}$ rate, corn plants produced $102.7 \mathrm{~g}$ dry matter per plant in the presence of sunn hemp, and $92.64 \mathrm{~g}$ in the presence of millet. The low $\mathrm{C} / \mathrm{N}$ and $\mathrm{C} / \mathrm{P}$ ratio in sunn hemp certainly favored the mineralization of its residues, with lesser immobilization of $\mathrm{N}$ and $\mathrm{P}$ from soil, which probably improved soil fertility, as observed in other studies (Carvalho et al., 2008, 2011; Silva et al., 2008; Asagi \& Ueno, 2009; Pypers et al., 2012; Sjursen et al., 2012).
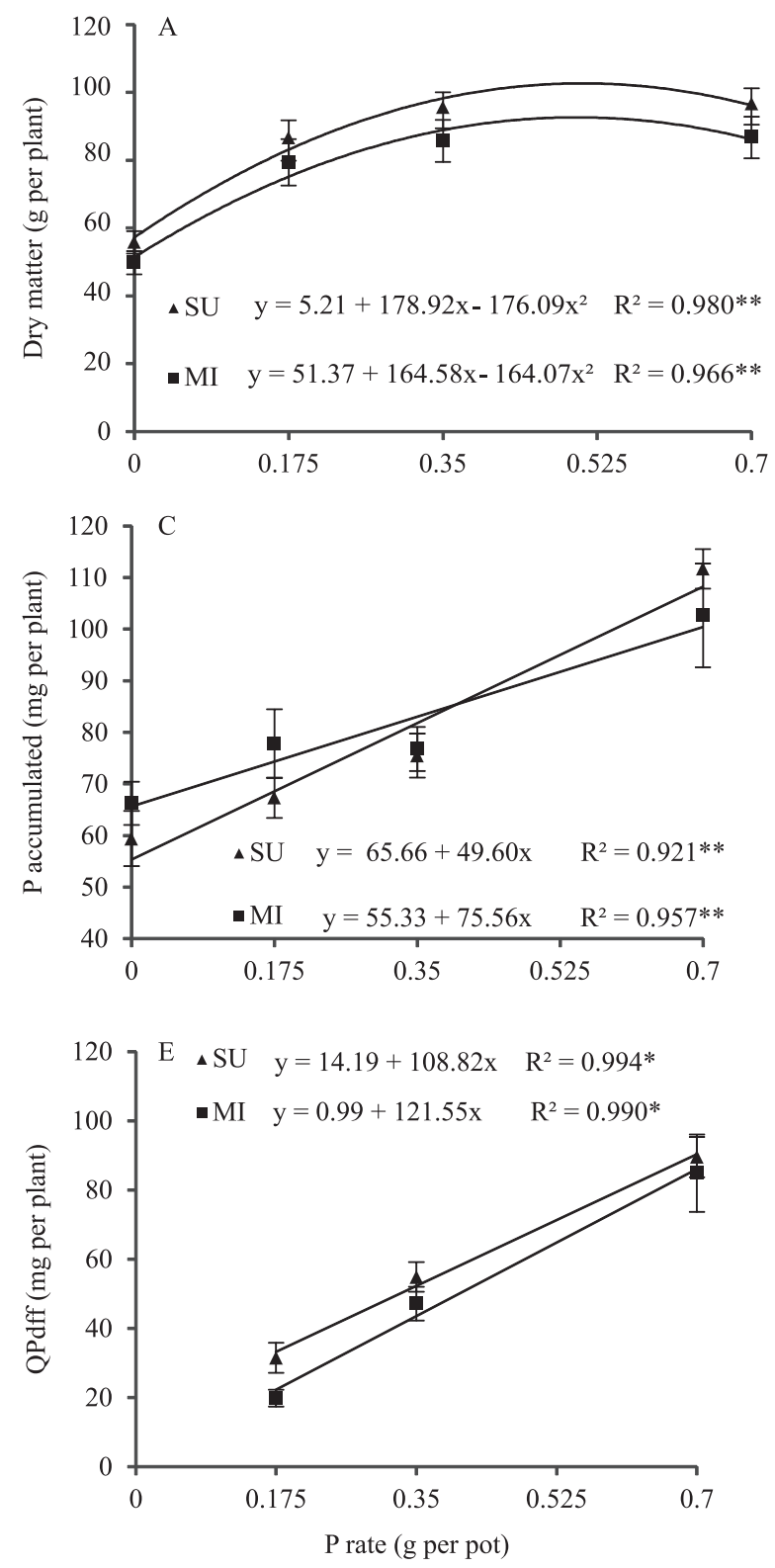

Phosphorus contents of corn shoots in the control treatment were similar to those in the highest $\mathrm{P}$ rate (Figure $1 \mathrm{~B}$ ), which, in part, was due to the lesser dry matter yield in the absence of $\mathrm{P}$ (control). In fact, $\mathrm{P}$ contents were little affected by $\mathrm{P}$ rates, due to the dilution effect of the increasing dry matter yield (Malavolta et al., 1997; Havlin et al., 2005; Marschner, 2011).

However, the amount of accumulated $\mathrm{P}$ in corn shoots was proportional to the applied $\mathrm{P}$ rate (Figure $1 \mathrm{C}$ ),
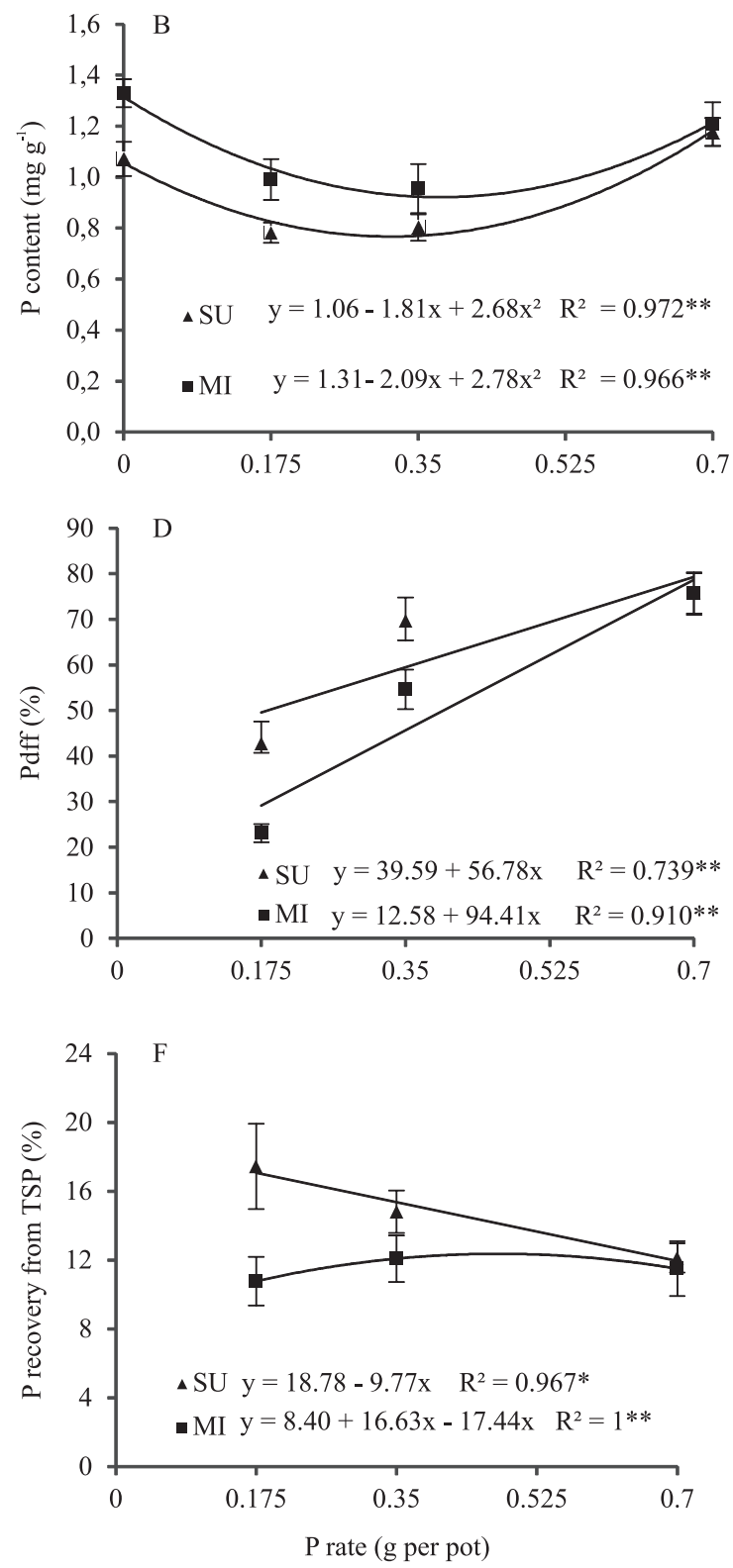

Figure 1. Effect of $P$ rates and green manures on: $A$, dry matter yield; $B$, shoot contents of $P$; $C, P$ accumulation in shoots; $\mathrm{D}$, percentage of $\mathrm{P}$ derived from fertilizer (\%Pdff); $\mathrm{E}$, amount of $\mathrm{P}$ in plant derived from fertilizer (QPdff); and F, P recovery from the ${ }^{32} \mathrm{P}-\mathrm{TSP}$. SU, sunn hemp residues; MI, millet residues. ${ }^{* *}$ and $*$ significant by the $\mathrm{F}$ test at 1 and $5 \%$, respectively. 
and was fitted to a linear model. Prochnow et al. (2004) obtained similar results with wheat plants. The percentage and the plant shoot-amount of $\mathrm{P}$ derived from the fertilizer (Figures $1 \mathrm{D}$ and $\mathrm{E}$ ) followed the linear behavior of accumulated P. This effect had also been verified by Franzini et al. (2009) in corn plants. Both variables, however, behaved differently in the presence of sunn hemp or millet, again, with higher values for sunn hemp, which agree with the greater $\mathrm{P}$ quantity provided by the millet $(0.220 \mathrm{~g}$ per pot $)$ compared to sunn hemp (0.160 g).

Organic amendments with a $\mathrm{P}$ content lower than $2.2 \mathrm{~g} \mathrm{~kg}^{-1}$ increase $\mathrm{P}$ sorption in the soil solid phase, and those with content higher than $2.2 \mathrm{~g} \mathrm{~kg}^{-1}$ reduce P sorption (Singh \& Jones, 1976). Although both sunn hemp and millet showed P contents higher than $2.2 \mathrm{~g} \mathrm{~kg}^{-1}$, at low $\mathrm{P}$ fertilizer rate $(0.175 \mathrm{~g}$ per pot), $\mathrm{P}$ recovery from TSP was 1.6 times higher (Figure $1 \mathrm{~F}$ ) by the addition of sunn hemp residues (P-TSP recovery
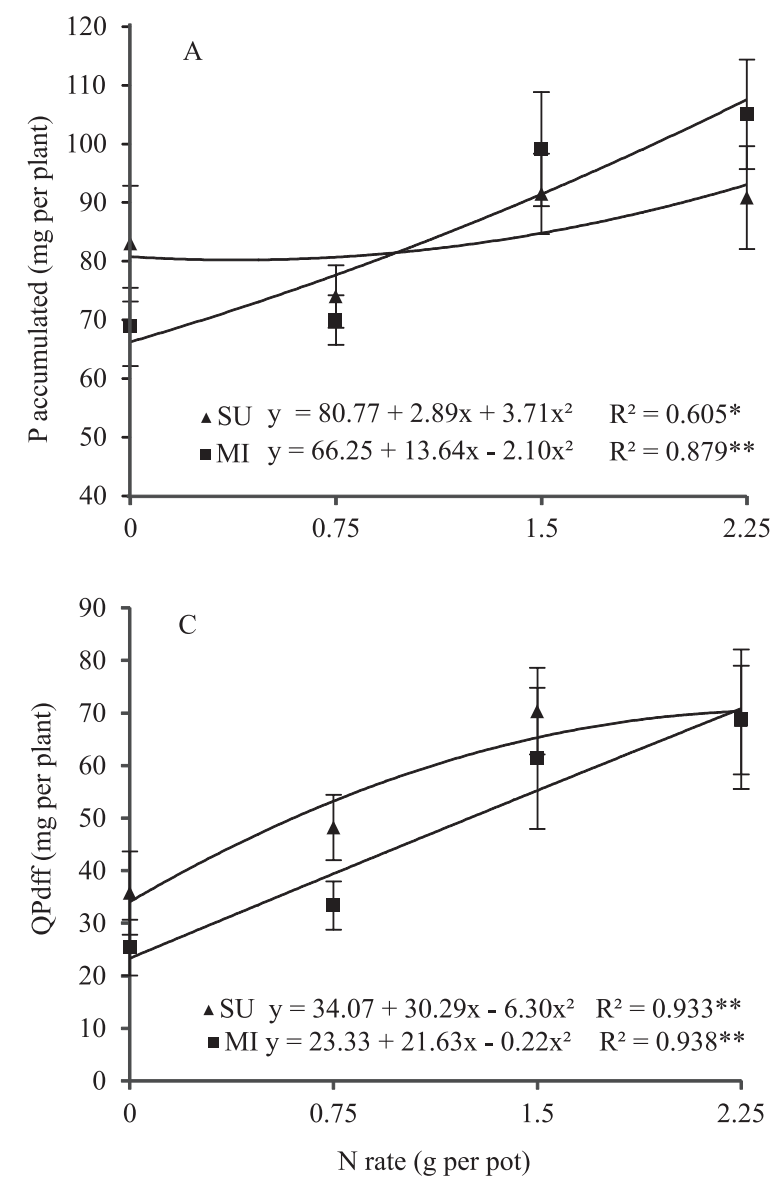

$=17.4 \%)$, compared to millet (P-TSP recovery $=10.8 \%)$. On average, $\mathrm{P}$ recovery from fertilizer was higher in the presence of sunn hemp residues $(14.79 \%)$, compared to millet (11.45\%). This effect probably occurred because sunnhemp residues decompose more easily in the short term than millet ones.

Nitrogen rates promoted the accumulation of $\mathrm{P}$ in the shoots (Figure $2 \mathrm{~A}$ ), the percentage and the amount of $\mathrm{P}$ derived from fertilizer (Figures $2 \mathrm{~B}$ and $\mathrm{C}$ ), and the recovery of $\mathrm{P}$ from this source (Figure $2 \mathrm{D}$ ), which suggest synergic effects between these nutrients on $\mathrm{P}$ absorption, as observed in other studies (Lee et al., 1992; Schlegel et al., 1996; Akinnifesi, et al., 2007; Oliveira et al., 2009). Phosphorus uptake was stimulated by the presence of $\mathrm{N}$, following a quadratic model, as also observed by Schlegel et al. (1996). Noteworthy, $\mathrm{P}$ recovery from the fertilizer was most significant for corn grown in the presence of sunn hemp compared to millet, regardless of the $\mathrm{N}$ rate.
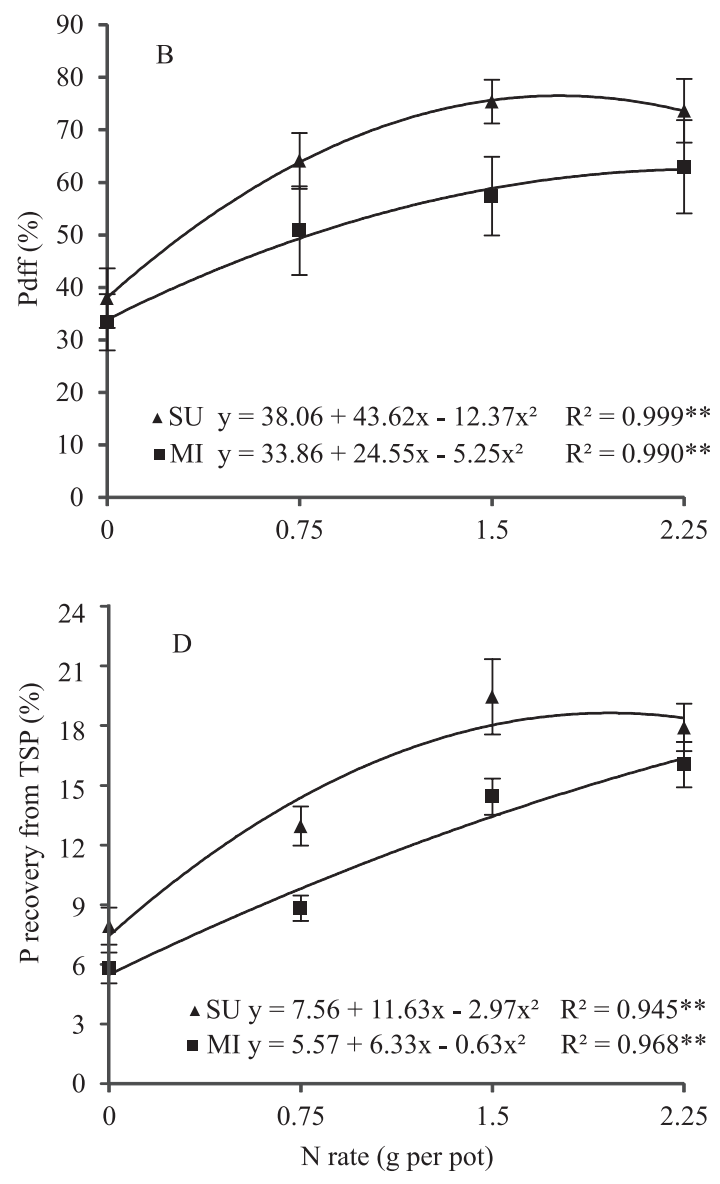

Figure 2. Effect of $\mathrm{N}$ rates and green manures on: $\mathrm{A}, \mathrm{P}$ accumulated in shoots; $\mathrm{B}$, percentage of $\mathrm{P}$ derived from fertilizer (Pdff); C, amount of P derived from fertilizer (QPdff); and D, ${ }^{32} \mathrm{P}-\mathrm{TSP}$ recovery. SU, sunn hemp residues; MI, millet residues. ** and * significant by the $\mathrm{F}$ test at 1 and $5 \%$, respectively. 
On average, the $\mathrm{P}$ recovery increased from 6.98 to $17.25 \%$ with $\mathrm{N}$ rates, and decreased from 14.11 to $11.81 \%$ with $\mathrm{P}$ rates. The overall average value $(13.12 \%)$ was slightly superior to the one reported by Franzini et al. (2009) (10.52\%). Studies carried out using the ${ }^{32} \mathrm{P}$ methodology have shown that $\mathrm{P}$ use efficiency by corn rarely surpass $10 \%$ (Chien et al., 1996; Franzini et al., 2009), contradicting the efficiency obtained by other methods. The variation in the $\mathrm{P}$ recovery from mineral fertilizers may have several causes, mainly those related to soil conditions, which exert great influence on P fixation capacity (Novais \& Smyth, 1999; Prochnow et al., 2004; Franzini et al., 2009).

The effect of $\mathrm{N}$ on $\mathrm{P}$ recovery from TSP was more intense in the treatments with higher $\mathrm{N}$ rates (1.5 or $2.25 \mathrm{~g} \mathrm{~N}$ per pot), almost three times greater than the ones that received $0.750 \mathrm{~g} \mathrm{~N}$ per pot (Figure $2 \mathrm{D}$ ). In general, $\mathrm{N}$ application doubled $\mathrm{P}$ recovery by corn plant, in comparison to the treatments in which $\mathrm{N}$ was omitted. Such an increase in the use of $\mathrm{P}$ can be expressive in economical and environmental terms. Similar results were reported by Schlegel et al. (1996).

In all treatments, most of the applied $\mathrm{P}$ remained in the soil at the end of the experiment. This suggests the need of adopting management practices that could help to maintain the residual $\mathrm{P}$ on labile forms. It has been evidenced that growing green manures is very important for the cycling of $\mathrm{P}, \mathrm{N}$ and of other essential nutrients in organic forms in soils (Pypers et al., 2005; Carvalho et al., 2008, 2011).

In corn plants, the percentage and the amount of $\mathrm{P}$ derived from soil $+\mathrm{GM}(\mathrm{Pdfs}+\mathrm{GM})$ decreased with increasing $\mathrm{P}$ (Figures $3 \mathrm{~A}$ and $\mathrm{C}$ ) and $\mathrm{N}$ rates (Figures $3 \mathrm{~B}$ and $\mathrm{D}$ ). The Pdfs $+\mathrm{GM}$ values were higher in the control treatment, and decreased linearly with
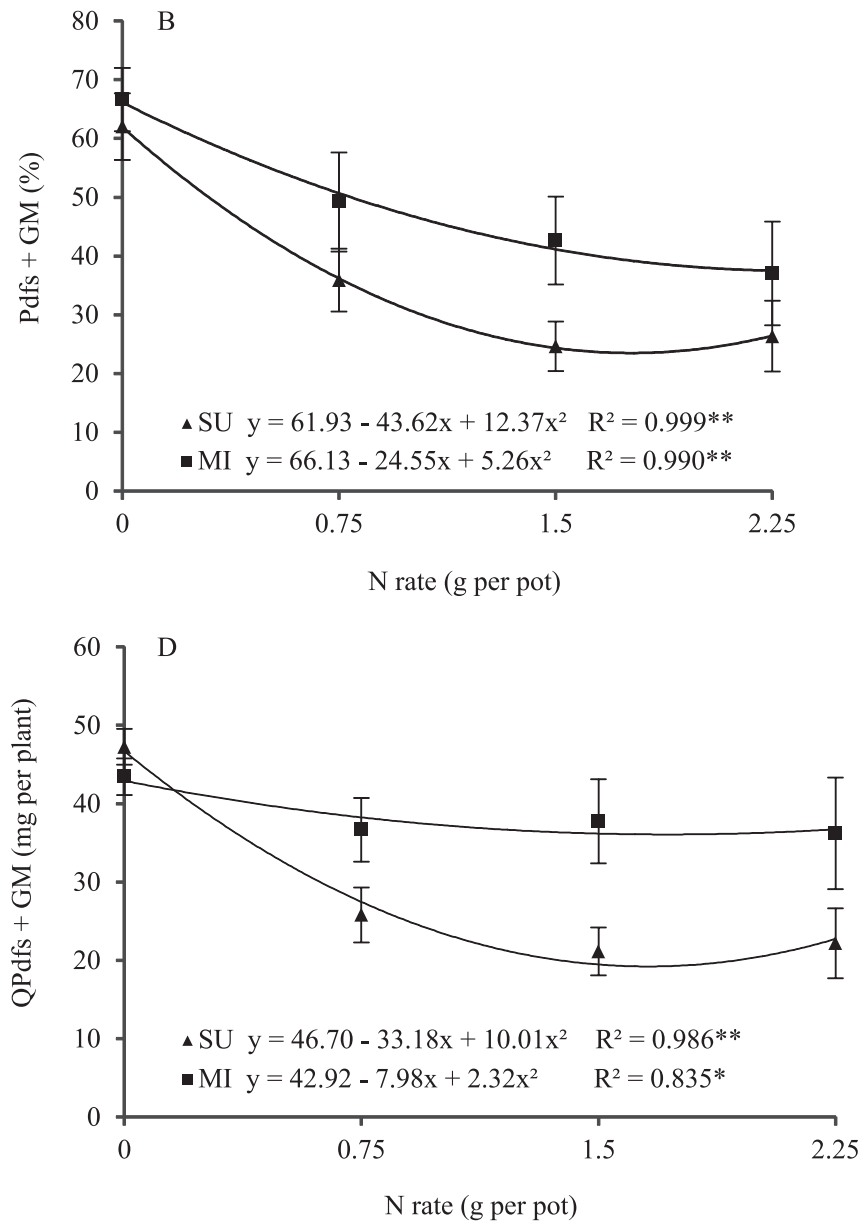

Figure 3. Effect of green manures on the percentage and amount of $\mathrm{P}$ derived from soil plus green manure (Pdfs $+\mathrm{GM})$, as affected by $\mathrm{P}(\mathrm{A}$ and $\mathrm{C})$ and $\mathrm{N}$ rates $(\mathrm{B}$ and $\mathrm{D})$. SU, sunn hemp residues; MI, millet residues. ** and * significant by the $\mathrm{F}$ test at 1 and $5 \%$, respectively. 
increasing $\mathrm{P}$ rates, or in quadratic form with increasing $\mathrm{N}$ rates. Phosphorus uptake from soil plus GM was most significant for corn grown in the presence of millet residues, compared to sunn hemp, regardless of $\mathrm{N}$ rate. This may have been induced by different mineralization processes between the GM residues and by the greater $\mathrm{P}$ quantity provided by millet.

It is worth mentioning that the P contained in the corn root system was not considered in this study; therefore, the overall $\mathrm{P}$ recovery value here is underestimated.

\section{Conclusions}

1. Phosphorus recovery from mineral fertilizer by corn plants is maximized with the appropriate $\mathrm{N}$ supply, which promote a synergic effect on the $\mathrm{P}$ absorption and on dry matter yield.

2. The mineral fertilizer provides most of the accumulated $\mathrm{P}$ for corn plants, and the nutrient recovery from this source on average reaches $13.12 \%$ of the amount applied.

3. The green manure species influences the assimilation of $\mathrm{P}$ from the fertilizer by corn plants.

4. The absorption of $\mathrm{P}$ derived from soil plus green manure decreased with the increasing rates of $\mathrm{N}$ and $\mathrm{P}$.

\section{Acknowledgements}

To Fundação de Amparo à Pesquisa do Estado de São Paulo, for research grant and for financial support; to the International Atomic Energy Agency, for financial support; and to Conselho Nacional de Desenvolvimento Científico, for research fellowship.

\section{References}

AKINNIFESI, F.K.; MAKUMBA, W.; SILESHI, G.; AJAYI, O.C.; MWETA, D. Synergistic effect of inorganic N and P fertilizers and organic inputs from Gliricidia sepium on productivity of intercropped maize in Southern Malawi. Plant and Soil, v.294, p.203-217, 2007.

ASAGI, N.; UENO, H. Nitrogen dynamics in paddy soil applied with various ${ }^{15} \mathrm{~N}$-labelled green manures. Plant and Soil, v.322, p.251-262, 2009.

BAH, A.R.; ZAHARAH, A.R.; HUSSIN, A. Phosphorus uptake from green manures and phosphate fertilizers applied in an acid tropical soil. Communications in Soil Science and Plant Analysis, v.37, p.2077-2093, 2006.

CARVAlHO, A.M. de; BUSTAMANTE, M.M. da C.; SOUSA JUNIOR, J.G. de A.; VIVALDI, L.J. Decomposição de resíduos vegetais em latossolo sob cultivo de milho e plantas de cobertura. Revista Brasileira de Ciência do Solo, v.32, p.2831-2838, 2008.

CARVALHO, A.M. de; SOUZA, L.L.P. de; GUIMARÃES JÚNIOR, R.; ALVES, P.C.A.C.; VIVALDI, J.L. Cover plants with potential use for crop-livestock integrated systems in the Cerrado region. Pesquisa Agropecuária Brasileira, v.46, p.1200-1205, 2011.

CHIEN, S.H.; MENON, R.G.; BILLINGHAM, K.S. Phosphorus availability from phosphate rock as enhanced by water soluble phosphorus. Soil Science Society of America Journal, v.60, p.1173-1177, 1996.

CHIEN, S.H.; PROCHNOW, L.I.; TU, S.; SYNDER, C.S. Agronomic and environmental aspects of phosphate fertilizers varying in source and solubility: an update review. Nutrient Cycling in Agroecosystems, v.89, p.229-255, 2011.

CHOI, B.; OHE, M.; HARADA, J.; DAIMON, H. Role of belowground parts of green manure legumes, Crotalaria spectabilis and Sesbania rostrata, in $\mathrm{N}$ uptake by the succeeding tendergreen mustard plant. Plant Production Science, v.11, p.116-123, 2008.

FAGERIA, N.K. Green manuring in crop production. Journal of Plant Nutrition, v.30, p.691-719, 2007.

FRANZINI, V.I.; MURAOKA, T.; MENDES, F.L. Ratio and rate effects of ${ }^{32} \mathrm{P}$-triple superphosphate and phosphate rock mixtures on corn growth. Scientia Agricola, v.66, p.71-76, 2009.

GRANT, C.A.; FLATEN, D.N.; TOMASIEWICZ, D.J.; SHEPPARD, S.C. The importance of early season phosphorus nutrition. Canadian Journal of Plant Science, v.81, p.211-224, 2001.

HAVLIN, J.L.; BEATON, J.D.; TISDALE， S.L.; NELSON, W.L. Soil fertility and fertilizers: an introduction to nutrient management. $7^{\text {th }}$ ed. New Jersey: Prentice Hall, 2005. 515p.

HAYNES, R.J.; MOKOLOBATE, M.S. Amelioration of Al toxicity and $\mathrm{P}$ deficiency in acid soils by additions of organic residues: a critical review of the phenomenon and the mechanisms involved. Nutrient Cycling in Agoecosystems, v.59, p.47-63, 2001.

HOCKING, P.J.; KEERTHISINGHE, G.; SMITH, F.W.; RANDALL, P.J. Comparison of the ability of different crop species to access poorly-available soil phosphorus. In: INTERNATIONAL PLANT NUTRITION COLlOQUIUM, 13., 1997, Tokyo. Plant nutrition for sustainable food production and environment: proceedings. Dordrecht: Kluwer Academic, 1997. p.305-308.

LARA CABEZAS, W.A.R.; ALVES, B.J.R.; CABALLERO, S.S.U.; SANTANA, D.G. de. Influência da cultura antecessora e da adubação nitrogenada na produtividade de milho em sistema plantio direto e solo preparado. Ciência Rural, v.34, p.1005-1013, 2004.

L'ANNUNZIATA, M.F. Radionuclide tracers: their detection and measurement. London: Academic, 1987. 505p.

LEE, R.B.; PURVES, J.V.; RATCLIFFE, R.G.; SAKER, L.R. Nitrogen assimilation and the control of ammonium and nitrate absorption by maize roots. Journal of Experimental Botany, v.43, p.1385-1396, 1992.

MALAVOLTA, E.; VITTI, G.C.; OLIVEIRA, S.A. de. Avaliação do estado nutricional das plantas: princípios e aplicações. 2.ed. 
Piracicaba: Associação Brasileira para Pesquisa da Potassa e do Fosfato, 1997. 319p.

MARSCHNER, H. Mineral nutrition of higher plants. $3^{\text {rd }}$ ed. London: Academic Press, 2011. 889p.

NACHIMUTHU, G.; GUPPY, C.; KRISTIANSEN, P.; LOCKWOOD, P. Isotopic tracing of phosphorus uptake in corn from ${ }^{33} \mathrm{P}$ labelled legume residues and ${ }^{32} \mathrm{P}$ labelled fertilisers applied to a sandy loam soil. Plant and Soil, v.314, p.303-310, 2009.

NOVAIS, R.F. de; ALVAREZ V., V.H.; BARROS, N.F. de; FONTES, R.L.F.; CANTARUTTI, R.B.; NEVES, J.C.L. (Ed.). Fertilidade do solo. Viçosa: Sociedade Brasileira de Ciência do Solo, 2007. 1017p.

NOVAIS, R.F. de; SMYTH, T.J. Fósforo em solo e planta em condições tropicais. Viçosa: Universidade Federal de Viçosa, 1999. 399p.

OLIVEIRA, F.A. de; CAVALCANTE, L.F.; SILVA, I. de F. da; PEREIRA, W.E.; OLIVEIRA, J.C. de; COSTA FILHO, J.F. da. Crescimento do milho adubado com nitrogênio e fósforo em um Latossolo Amarelo. Revista Brasileira de Ciências Agrárias, v.4, p.238-244, 2009.

PROCHNOW, L.I.; CHIEN, S.H.; CARMONA, G.; HENAO, J. Greenhouse evaluation of phosphorus sources produced from a low-reactive Brazilian phosphate rock. Agronomy Journal, v.96, p.761-768, 2004.

PYPERS, P.; BIMPONDA, W.; LODI-LAMA, J.-P.; LELE, B.; MULUMBA, R.; KACHAKA, C.; BOECKX, P.; MERCKX, R.; VANLAUWE, B. Combining mineral fertilizer and green manure for increased, profitable cassava production. Agronomy Journal, v.104, p.178-187, 2012.

PYPERS, P.; VERSTRAETE, S.; THI, C.P.; MERCKX, R. Changes in mineral nitrogen, phosphorus availability and salt-extractable aluminum following the application of green manure residues in two weathered soils of South Vietnam. Soil Biology and Biochemistry, v.37, p.163-172, 2005.

RAIJ, B. van; ANDRADE, J.C. de; CANTARELLA, H.; QUAGGIO, J.A. Análise química para avaliação da fertilidade de solos tropicais. Campinas: Instituto Agronômico, 2001. 285p.

RYAN, J.; IBRIKCI, H.; SINGH, M.; MATAR, A.; MASRI, S., RASHID, A. PALA, M. Response to residual and currently applied phosphorus in dryland cereal/legume rotations in three Syrian Mediterranean agroecosystems. European Journal of Agronomy, v.28, p.126-137, 2007.

SANTOS, H.G. dos; JACOMINE, P.K.T.; ANJOS, L.H.C. dos; OLIVEIRA, V.A. de; OLIVEIRA, J.B. de; COELHO, M.R.; LUMBRERAS, J.F.; CUNHA, T.J.F. (Ed.). Sistema brasileiro de classificação de solos. 2.ed. Rio de Janeiro: Embrapa Solos, 2006. $306 \mathrm{p}$.

SARRUGE, J.R.; HAAG, H.P. Análises químicas em plantas. Piracicaba: ESALQ, 1974. 57p.

SAS INSTITUTE. SAS user's guide: statistics. Versão 8.2. Cary: SAS Institute, 2001.

SCHLEGEL, A.J.; DHUYVETTER, K.C.; HAVLIN, J.L. Economic and environmental impacts of long-term nitrogen and phosphorous fertilization. Journal of Production Agriculture, v.9, p.114-118, 1996.

SILVA, E.C. da; MURAOKA, T.; BUZETTI, S.; ESPINAL, F.S.C.; TRIVELIN, P.C.O. Utilização do nitrogênio da palha de milho e de adubos verdes pela cultura do milho. Revista Brasileira de Ciência do Solo, v.32, p.2853-2861, 2008.

SINGH, B.B.; JONES J.P. Phosphorus sorption and desorption characteristics of soil as affected by organic residues. Soil Science Society of America Journal, v.40, p.389-394, 1976.

SJURSEN, H.; BRANDSAETER, L.O.; NETLAND, J. Effect of repeated clover undersowing, green manure ley and weed harrowing on weeds and yields in organic cereals. Acta Agriculturae Scandinavica, Section B - Soil and Plant Science, v.62, p.138-150, 2012.

SPERA, S.T.; CORREIA, J.R.; REATTO, A. Solos do bioma Cerrado: propriedades químicas e físico-hídricas sob uso e manejo de adubos verdes. In: CARVALHO, A.M. de; AMABILE, R.F. (Ed.). Cerrado: adubação verde. Planaltina: Embrapa Cerrados, 2006. p.41-70.

UNITED STATES. Department of Agriculture. Natural Resources Conservation Services. Soil survey staff: keys to soil taxonomy. $10^{\text {th }}$ ed. Washington: URCS, 2006.

VOSE, P.B. Introduction to nuclear techniques in agronomy plant biology. London: Pergamon, 1980. 391p.

Received on September 27, 2011 and accepted on June 13, 2012 